\title{
Incentive Mechanisms of Human Resource Management (HRM) in Private Academic Institutions in Ghana
}

\author{
Irene Samari* \\ Nanjing University of Posts and Telecommunications, China
}

*Corresponding Author: Irene Samari, Nanjing University of Posts and Telecommunications, China

\begin{abstract}
Innovative Human Resource Management (HRM) is a widespread practice among educational entities of today. With the goal of increasing employees' motivation towards increased productivity, educational entities are seeking to apply themselves to various incentive mechanisms. Studies suggest that incentives play a key role in influencing employee performance. The purpose of this research is to analyze the incentive mechanisms of human resource management in educational institutions, and to find out the effect of employees' motivation on organizations and the different types of motivations. The paper also brings to bear insights on what motivates employees to work better for the overall benefit of an organization.

The results of the study indicated that for employees to put in more extra efforts is based on the incentives they receive which motivates them to perform better. The study suggested ways by which incentive mechanisms can be improved in Ashesi University. The study also recommends the human resource management should develop effective human resource practices through an appropriate rewarding system, as well a good performance management system, with effective monitoring and supervising teams.
\end{abstract}

Keywords: Incentive Mechanisms, Human Resource Management, Staff Performance

\section{INTRODUCTION}

The educational sector in our modern world is a highly competitive environment especially among private academic institutions which aim at balancing profitability with quality education delivery. To ensure that they keep up with such high levels of competition whiles ensuring that stakeholder interest are still high, educational institutions seek strategies that will cater to the benefit of students and other stakeholders as a whole. Ghana's educational sector is no exception to such competition. The major responsibility of educational institutions is to maximize returns to stakeholders. Though this may seem straightforward, it does entail many complex facets; such as setting out short-term and longterm plans, the need to regulate and control expenditure whiles investing in fixed and human assets, the maintenance of competitiveness among colleague institutions, and achieving the highest possible productivity from all available assets including employees. Such a responsibility can be a herculean task when dealing with employees who are relatively unmotivated. Thus, it has become necessary for managers of educational institutions to be mindful of the pressures of employee expectations as well as those of stakeholders and try as much as possible to devise strategies to meet them.

A strategy to keep and lure expert labor into the higher educational sector is incentivization. Incentive is a very important component in the development of human institutions. According to Armstrong and Armstrong [1] incentivization typically inculcates a system of profit sharing, employee stock ownership plans, bonus payments, and non-cash benefits and Employee Stock. Baron [2] and Laffont and Martimort [3] assert that there is massive attention been drawn to the need to motivate employees in order to induce improved performance whenever possible. With economic issues becoming more a visible part of Ghana's educational sector, one cannot imagine any period for the issue of motivation to be discussed. With employees' salaries representing close to $60 \%-70 \%$ of budgeted education institution expenditure, [4] the ability to utilize such human resources effectively and efficiently has become an issue of paramount concern. [5]

The use of incentives to give directions to such individual energies and behavior of human resources should not be limited only to the corporate world but also educational institutions can make such a practice thus "satisfying each and every one of the needs from hunger to self-actualization. [6] 


\section{LITERATURE REVIEW}

Motivation and employee incentivization have been extensively researched by notable authors in the field. In this view, it is useful to review some of the significant theories forwarded and accepted by these authors. Each person is motivated differently and it would be helpful to identify what makes them tick in order to align employees' goals to the organizational goals. Over the years, many theorists have attempted to explain the complexity of motivation in the workplace. Each theoretical perspective illuminates how motivation influences work performance.

\subsection{Incentive and Incentive Mechanisms}

An incentive mechanism is a treatment or measure that is used to motivate and encourage people. Stavrou, ${ }^{[12]}$ maintains that an incentive could be a combination of a personal drive and extrinsic motivation that is capable of pushing people beyond their limits. For instance, to participate in a learning network, to encourage an employee to put in maximum efforts at work or even to make an employee stop a particular behavior or practice. A mechanism that has been found plausible in the field of human resource in identifying and attracting qualified human capital, whiles ensuring motivation in order to derive maximum efforts at jobs is incentives. Thus, the conclusion drawn by Cadsby et al, ${ }^{[13]}$ that well-paid staffs does have increased productivity.

However, defining incentives has been wide and varied as well as sector specific. In relation to the health sector, ${ }^{[14]}$ understood incentives as rewards and punishments entertained by healthcare providers as a result of their relative work environment; and this is in support of earlier assertions made by Imhorf and Mathauer, ${ }^{[15]}$ that incentives are conduits for influencing physicians and nurses to exert and maintain willingly efforts directed at achieving set goals and targets in various health institutions. The educational sector views incentives as a tool aimed at encouraging student to increase work and study performance. Furthermore, incentives are visualized as external undertakings designed and established with the basic purpose of directing individual, group or organizational motivation. ${ }^{[16]}$

Whiles Burkhauser et al, ${ }^{[17]}$ stated that such tangible and intangible rewards acting as a motivational medium for individual or group behavior is incentives; Moser et al, ${ }^{[18]}$ opine that incentives are techniques employed by organizations which go to ensure their compliance with the employment contract, thus acting as compensation to its employees.

However, Stilwell et al, ${ }^{[19]}$ make a definite statement on what incentives are by stating that incentive is "an explicit or implicit financial or non-financial reward geared towards undertaking of specific task". The derivative to be made from the above definitions is that defining incentives, though been wide and varied, it does have a core concept which is intangible and tangible reparations. Also, it is an explicit or implicit way of influencing individual or group acts in particular direction, which is mostly achievement of set goals and target.

\subsection{Content - Type Incentive Theory}

Content theories attempt to explain what drives individuals to act in a certain manner based on a universal understanding that all human beings have needs to satisfy. However, there are several limitations these approaches can contribute in practice due to the complexity of human nature. As such, it is important for organizational managers to know what employees need and also their needs will evolve over time while bearing in mind that needs differ considerably among employees. Subsequently design a flexible reward system ${ }^{[20]}$ to adapt to various needs of the employees. In this case, the needs of employees will determine the effectiveness of incentives used to motivate them.

\section{HIERARCHY OF NEEDS}

One of the most well-known easily comprehensible motivational theories was propounded by American psychologist Abraham Maslow, who conceptualized the infamous five stages of needs that influence human motivation as illustrated below:

Physiological needs such as food, air, water and shelter outline the basis for motivation and are necessary to ensure the continuation of human life. Safety needs are required by individuals to feel protected from emotional and physical jeopardy. Organizations can satisfy these needs by providing safe working environment, job security and retirement benefit package. 


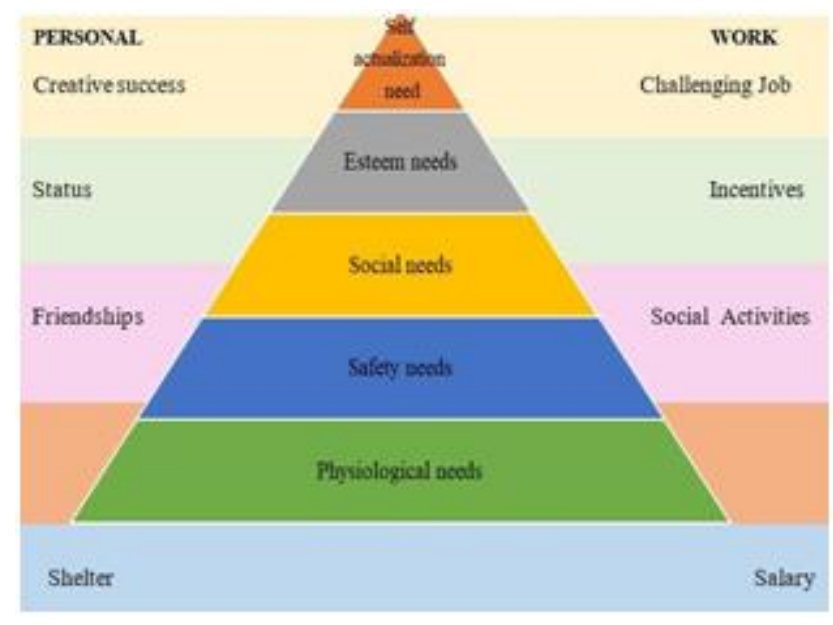

Figure1. Maslow's hierarchy of needs ${ }^{[21]}$

Belongingness needs refer to the need for affiliation and group identification individuals obtain from family members, friends, colleagues etc. This includes, but not limited to friendship, social interaction, belongingness, or acceptance by others.

Esteem needs can be simply described as feeling good about oneself. Self- esteem and personal accomplishment through challenging assignments are part of internal esteem needs while nice job titles, recognition, rewards and reputation are external esteem needs. ${ }^{[22]}$

Self-actualization is the pinnacle level of attainment in the need hierarchy. It implies that the full potential of an individual has been realized. This need, however, is hard for a manager to address as it is completely up to the employee's desire to achieve. Griffin, ${ }^{[21]}$ suggests that managers can help foster an environment where attaining self-actualization is possible for instance empower employees to make decisions about work and providing opportunities for self-development. As observed by Maslow, this need is never entirely fulfilled as the individual will continue to seek growth opportunities. Maslow once suggested that only 2 percent of the human population actually achieve self-actualization. ${ }^{[23]}$

Maslow concluded that individuals are primarily motivated by unsatisfied needs in an ascending scale. This concept is termed 'satisfaction-progression processes or prepotency whereby individuals will proceed to fulfill a next higher level need only after a lower level need of the hierarchy is fully satisfied. In other words, an individual whose physiological needs are unmet will not escalate to fulfill the next layer i.e. safety needs; instead will motivate oneself to persevere until the currently recognized need is satisfied. ${ }^{[24]}$

\subsection{ERG Theory}

Alderfer revised Maslow's theory of hierarchical needs by reclassifying the five-level pyramid into three broader categories of human needs:

Existence needs combines Maslow's physiological and safety needs. It simply refers to essential needs for survival such as food, shelter, and safe working environment. Relatedness needs is similar to social needs of Maslow's theory; a need for individuals to sustain interpersonal relationships and to feel connected to others. Extrinsic motivation also falls within this category. Growth needs encompasses esteem needs and self-actualization of Maslow's theory. This is a need consisting of self-improvement; develop intrinsic motivation for task through accomplishments; complete meaningful task and be creative.

Unlike Maslow, Alderfer contends an individual may be motivated by two or three need categories at the same time where one need appears more dominant than the other. This is known as the 'frustration-regression process' whereby if an individual who is unable to satisfy the growth need will regress to relatedness need which continues to be a strong motivator. ${ }^{[24]}$

\subsection{Two Factor Approach}

Herzberg's motivation-hygiene approach, a theory closely connected to the corporate world, was 
derived from an empirical experiment conducted on employees to determine job satisfaction. Determinants entailing satisfaction are labelled as motivators, whereas hygiene factors tend to lead to dissatisfaction. Individuals will strive to satisfy hygiene needs so as to reduce dissatisfaction but do not necessarily induce long-term satisfaction but inadequate or the absence of good hygiene factors will cause dissatisfaction. However, dissatisfaction will not result from unsatisfied intrinsic needs nor reduce dissatisfaction when these needs are met. ${ }^{[25]}$ Motivation factors are related to work content while hygiene factors are related to work environment, ${ }^{[21]}$ as summarized below:

Table1. Hygiene and motivation factors affecting job attitudes

\begin{tabular}{|l|l|}
\hline \multicolumn{1}{|c|}{ Motivation factors (Intrinsic) } & \multicolumn{1}{c|}{ Hygiene factors (Extrinsic) } \\
\hline Achievement & Company policies and administration \\
\hline Recognition & Interpersonal relations \\
\hline Responsibility & Working conditions \\
\hline Work itself & Salary \\
\hline Advancement & Job security \\
\hline Personal growth & Status Benefits \\
\hline
\end{tabular}

According to Herzberg et al., ${ }^{[25]}$ managers should avoid placing strong emphasis on fulfilling hygiene needs as this will result in employees relying too heavily on extrinsic rewards and may pose impediments to the long term success of the organization. Instead, managers should focus on designing more intrinsically challenging task, provide recognition and empowering employees when certain level of ability is demonstrated, which are the true motivators, when fulfilled, contribute to long-term positive effect on employees' job performance.

\subsection{Process-Type Incentive Theory}

Process theories explain how individuals are motivated. In this perspective, 'need' accounts for one component of the process through which individuals decide how to behave. Another component could possibly be for rewards. For instance, an employee perceives a reward (e.g. gift certificate) will be given for exhibiting certain behavior (e.g. working diligently), so this reward turns into a motive for that behavior. ${ }^{[26]}$

\subsection{Expectancy Theory}

Vroom's expectancy theory suggests that motivation levels of employees depend on three guiding principles:

- Expectancy (E-P) is the probability that exerting effort will lead to high levels of performance. For E-P to be positive, the employee must possess the appropriate skills, education, experience and necessary training to perform.

- Instrumentality (P-O) refers to the employee's perception that performance will lead to the desired outcome. The P-O expectancy will be positive if the employee believes good performance will result in a promotion or pay rise.

- Valence refers to how the employee perceives the attractiveness of the reward. The attractiveness of each reward differs between employees. For valence expectancy to be positive, organizational managers need to determine the kinds of available rewards the employee values the most. The reward may be monetary or non-monetary.

According to Vroom, motivation level can be computed using the following formula:

\section{Motivation = Expectancy $\mathrm{x}$ Instrumentality $\mathrm{x}$ Valence}

The theory advocates that motivation is present only when employees perceive a positive correlation that effort leads to job performance and job performance leads to rewards. ${ }^{[21]}$ To put in simply, if the strength of either expectancy or instrumentality or valence is zero or insignificant, there will be no motivation. If an employee who has the ability to perform well does not expect a reward or does not find the reward attractive, then he/she will not be so motivated to do the job. For motivation levels to be high, all three factors must be high too. It is clear, from the expectancy theory, that incentives play a crucial role in motivating employees. 


\subsection{Equity Theory}

Adam's equity theory is used to explain how employees judge the fairness of rewards received in proportion to resources invested for completing a task by assessing one's own investment-reward ratio, and compare it against the ratio of another colleague holding a similar position. ${ }^{[2]} \mathrm{A}$ comparison can be made using the formula below:

$$
\frac{\text { Outcomes }(\text { Individual })}{\text { Inputs }(\text { Individual })}=\frac{\text { Outcomes }(\text { Other })}{\text { Inputs }(\text { Other })}
$$

Investments made by the employee are termed 'inputs' while rewards are known as "outcomes". In order to receive outcomes such as extrinsic rewards and/or intrinsic rewards, the employee must first invest inputs such as time, commitment, effort, and experience.

One of the following three may result from the above equation. The most ideal situation would be the employee feels equitable in terms of reaping the rewards sowed relative to a fair comparison with the other. Conversely, an unbalanced equation may indicate that the employee is over-rewarded or underrewarded. The over-rewarded employee may feel compelled to be more productive. Whereas in the case of under-reward, the employee will seek equilibrium by lowering input or negotiating a pay rise or, in the worst scenario, leave the organization. ${ }^{[27]}$

\subsection{Behavior Modification}

B.F. Skinner's behavior modification theory was built on the model of operant conditioning that uses stimuli such as reinforcements, punishment or extinction to elicit acceptable behaviors and curtailing undesirable behaviors. ${ }^{[28]}$ This theory does not recognize that employees are motivated by needs or a process of motivation. Instead, it deals with how an employee's future actions are based on consequences of past actions. A behavior associated with rewarding consequences tends to be repeated and other behaviors that evoke unfavorable consequences are likely to be avoided. [29] According to McShane et al, ${ }^{[24]}$ research often proved the technique successful in modifying behavior as organizations see employees working more efficiently and learning more quickly than before.

\section{Methodology}

The methodology adopted for this study is the descriptive survey methodology. According to Cohen, Manion \& Morrison ${ }^{[11]}$ descriptive research is concerned with the conditions or relationships that exist, practices that prevail, beliefs or attitudes that are held, processes that are on-going, effects that are being felt or trends that are developing. The descriptive research design was used in this study due to its ability to enable the researcher collect quantitative data and analyze it using descriptive statistics based on which inferences can be made. The population for this study comprised all members of staff of three purposively selected private universities in Ghana namely Wisconsin International University College, Ashesi University and Christ Apostolic University College. A total sample of two hundred and fifty (250) respondents consisting of both academic and nonacademic staff was chosen using cluster and random sampling techniques. This was done to get a fair representation of all staff categories in the sample.

The main instrument employed for data collection was questionnaire. The questionnaire employed was the semi structured type consisting of both open-ended and close ended questions. The questionnaire was divided into five (5) distinct sections numbered (A) to (E). The first part of the questionnaire sought respondents' demographic data such as age, sex, work experience, education, etc. The rest of the sections, which is 'B' to 'E', sought to elicit information on the basic objectives of the study as outlined in chapter one of this write up. The researcher used descriptive statistics such as frequency distribution, and percentages, means and standard deviations in analyzing the data. The organized and coded data was then fed into the Statistical Package for Social Sciences (SPSS Software) for analysis and interpretation. The analysis and interpretation are presented under Chapter Four of this study.

\section{RESULTS AND DISCUSSION}

This section presents the results obtained after collating and processing of data through questionnaire administration. 


\subsection{Problems Facing Human Resource Management in Private Universities}

The idea of institutions providing incentive packages for staff has its own problems. Whiles one organization may see it as a morale booster for employees to go beyond their mark, another may see incentives a mere waste of resources. ${ }^{[30]}$ This is mostly argued on the premise that workers are hired and paid to do their jobs, so why spend another resource to motivate these workers who already get their remunerations for what they do. Most staff also do not take into consideration the multi system mode of incentive packages available but focus on the direct and immediate monetary gains. Sometimes, there is inadequate top management support and this makes it difficult for the low-level staff appreciates the incentive packages and policies.

Table2. Problems of Incentivization in private educational institutes

\begin{tabular}{|l|c|c|c|c|c|c|c|}
\hline \multicolumn{1}{|c|}{ Variables } & SD & $\mathbf{D}$ & $\mathbf{N}$ & $\mathbf{A}$ & $\mathbf{S A}$ & $\begin{array}{c}\text { Mean } \\
(\underline{\boldsymbol{x}})\end{array}$ & Rank \\
\cline { 2 - 8 } & $\mathbf{\%}$ & $\mathbf{\%}$ & $\mathbf{\%}$ & $\mathbf{\%}$ & $\mathbf{\%}$ & 3.30 & 3 \\
\hline Compensation & - & $40 \%$ & $10 \%$ & $30 \%$ & $20 \%$ & 3.90 & 5 \\
\hline Leadership development & - & $50 \%$ & $20 \%$ & $20 \%$ & $8.3 \%$ & 2.90 & 2 \\
\hline $\begin{array}{l}\text { Staffing, recruitment, availability of } \\
\text { skilled labor and retention }\end{array}$ & - & $30 \%$ & $10 \%$ & $40 \%$ & $20 \%$ & 3.50 & \\
\hline Organizational effectiveness & $10 \%$ & $30 \%$ & $10 \%$ & $30 \%$ & $20 \%$ & 3.20 & 4 \\
\hline Learning and development & - & $30 \%$ & $20 \%$ & $40 \%$ & $10 \%$ & 3.30 & 3 \\
\hline Succession planning & - & $20 \%$ & $20 \%$ & $40 \%$ & $20 \%$ & 3.60 & 1 \\
\hline Change management & - & $10 \%$ & $40 \%$ & $40 \%$ & $10 \%$ & 3.50 & 2 \\
\hline Health management & $10 \%$ & $20 \%$ & $20 \%$ & $30 \%$ & $20 \%$ & 3.30 & 3 \\
\hline
\end{tabular}

Key: $S D=$ Strongly Disagree, $D=$ Disagree, $N=$ Neutral, $A=$ Agree, $S A=$ Strongly Agree.

Problems of incentivization in private educational institutes regarding compensation and incentives; leadership development; Staffing: Recruitment and availability of skilled labor and retention; Organizational Effectiveness; Learning and development; Succession planning; Change management and Health and safety are depicted in Table 2. The responses were ranked based on their mean scores. The highest mean-scored incentive technique which is succession planning was ranked one (1) or first giving a strong indication that educational institutions faced a major problem in handling this incentive technique. Change management and staffing were ranked in second place as being the next problematic after succession planning. Change management refers to all the approaches to prepare and support individuals, teams, and organizations in making organizational change. This can be seen as a de-incentive especially when there's reshuffling of staff in various departments of the organization. Compensation, learning and development and health management equally ranked in third place. This means that they were less problematic as they are straight forward and easy to handle. Organizational effectiveness and Leadership development ranked fourth and fifth positions respectively as being the least problematic incentive techniques used by private tertiary educational institutions.

\subsection{Factors that Influence Staff Performance in Private Universities in Ghana}

It is an undeniable fact that there are a mix of factors that variously influence the performance of employees/staff in any institution. Since job satisfaction leads to increased performance, the researcher sought from respondents how satisfied they were with the current job incentives at their various institutions. This result is presented in Figure 2.

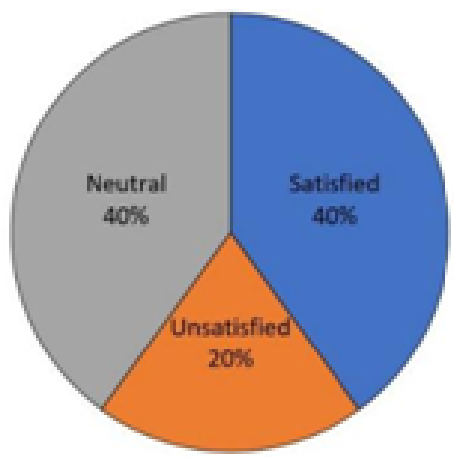

Figure2. Satisfaction with job incentives 
It is seen from the figure that $40 \%$ respondents were satisfied with current job incentives at their workplace whilst $20 \%$ were unsatisfied. There was however a large percentage of $40 \%$ who rather were neutral. This gives the general notion that staff in the various private tertiary educational institutions are moderately satisfied with the incentives they receive in their workplace.

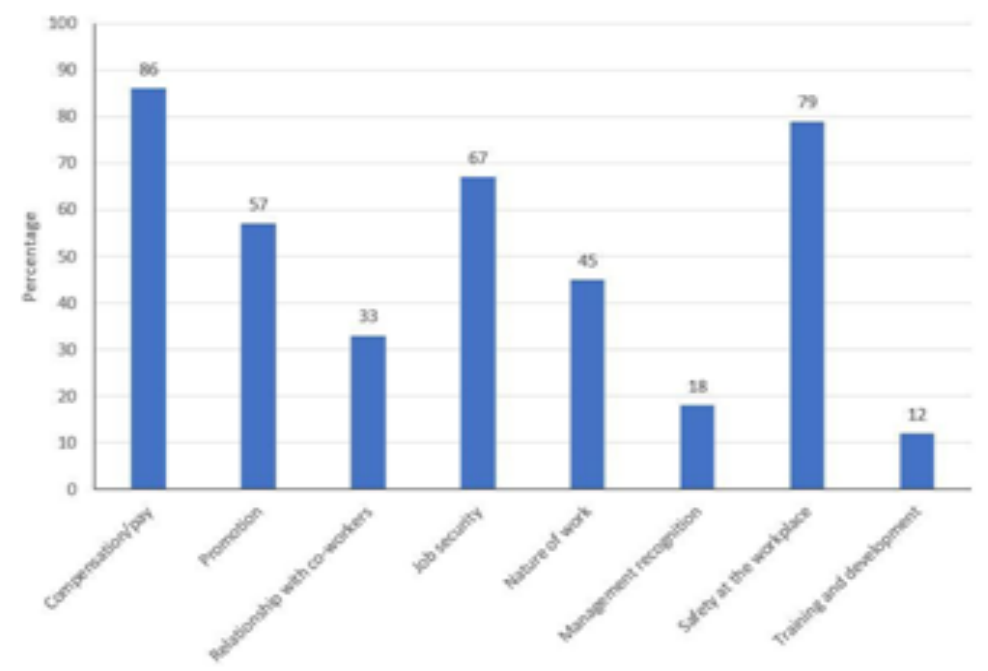

Figure3. Incentive factors that determine employee motivation

The data presented in Figure 3 indicates that financial compensation or pay is highly valued by employees as an incentive factor that determines their job satisfaction and consequently performance. Respondents reported safety at the workplace as the second most important job satisfaction element which recorded $79 \%$ of responses. Again, respondents ranked job security third in line as important in determining their job satisfaction and performance with a percentage of $67 \%$. Next was promotion opportunities followed by nature of work which scored $57 \%$ and $45 \%$ of responses respectively. According to the data, the least factor that predict employees job satisfaction is training and development followed by management recognition. These received percentage values of $12 \%$ and $18 \%$ respectively.

The above results show that financial rewards rank high among workers as incentive factors followed by congenial working environment or job security as shown in the data. This is corroborated in the literature by Heany et al., ${ }^{[36]}$ who in their research of 207 automobile workers found that job satisfaction decreases when employment insecurity is prolonged. Ahmed et al., ${ }^{[37]}$ in their research covering 5,729 managers found that, there was a negative relationship between job security and level of economic uncertainty. Silla et al., ${ }^{[38]}$ in their research among 639 workers from six higher institutions found that, employment security relates with well-being but job security did not and also the high perception of job security will also result in higher job satisfaction.

\subsection{Proposed Measures to Improve Human Resource Incentivization in Private Universities in Ghana}

There's much research evidence to prove that incentives cause employees to go the extra mile and do what they ordinarily would not do. However, there are different incentive techniques that are applicable to different contexts and organizations. It is not guaranteed that certain measures or techniques that work incentives in a particular institution will achieve the same effect in a different organization. To this effect, the researcher sought from the employees the kind of incentive factors that are particularly important to them as staff of educational institutions in Ghana. These are presented in Tables 3 and 4.

Table3. Incentive factors that are important to employees

\begin{tabular}{|c|c|c|c|c|c|}
\hline \multirow[t]{2}{*}{ Variables } & 1 & 2 & 3 & \multirow{2}{*}{$\begin{array}{c}\text { Mean } \\
(\underline{x})\end{array}$} & \multirow[t]{2}{*}{ SD } \\
\hline & $\%$ & $\%$ & $\%$ & & \\
\hline Receiving formal recognition for your effort & $20 \%$ & $40 \%$ & $40 \%$ & 2.20 & .751 \\
\hline Being recognized among coworkers for effort & $40 \%$ & $40 \%$ & $20 \%$ & 1.80 & .751 \\
\hline Feeling a spirit of team work and cooperation & $40 \%$ & $30 \%$ & $30 \%$ & 1.90 & .833 \\
\hline
\end{tabular}


Incentive Mechanisms of Human Resource Management (HRM) in Private Academic Institutions in Ghana

\begin{tabular}{|l|c|c|c|c|c|}
\hline Feeling that your work is valued and appreciated & - & $50 \%$ & $50 \%$ & 2.50 & .501 \\
\hline Bonuses and other financial incentives & $30 \%$ & $30 \%$ & $40 \%$ & 2.10 & .833 \\
\hline Opportunities for promotion/career growth & $40 \%$ & $20 \%$ & $40 \%$ & 2.00 & .897 \\
\hline Participation in teamwork & $50 \%$ & $30 \%$ & $20 \%$ & 1.70 & .783 \\
\hline
\end{tabular}

Key: 1 = Not important, 2 = Important, 3 = Most important .

In Table 3, respondents were asked what factors are important to them as employees in the workplace to motivate them. In a similar fashion, respondents rated bonuses and financial incentives among the top three factors that motivate them. The first factor in this instance is the feeling that one's work is valued and appreciated which scored the highest mean value of 2.50. The individual responses show that, $50 \%$ rated it as most important whilst the remaining $50 \%$ rated it as important thereby scoring that high mean value. This was followed by receiving formal recognition for one's efforts. This had a mean value of 2.20 then followed by bonuses and financial incentives with 2.10 as the mean score. The reason for the above two factors coming up before financial rewards is that these two are related to job security.

According to literature, employees are most likely to show commitment to their work when they are aware that their performance is being monitored and that the job would be reviewed and given the necessary recognition. ${ }^{[39]}{ }^{[40]}$ Nsiah-Gyabaah, ${ }^{[39]}$ further shows that some polytechnics and universities have been able to achieve their objectives resulting from strong evaluation of employees' performance whilst the opposite is true for institutions which have not been evaluating their employees' performance.

From the data, teamwork received the least mean value of 1.70 which indicates that it is the least important to employees to motivate or incentivize them. This is at variance with several research findings. ${ }^{[41][42]}$ Indeed, Cohen and Bailey, ${ }^{[41]}$ opined in the literature that higher institutions which emphasize more on teams have results in increased employee performance, greater productivity and better problem solving at work. They further pointed out on the other hand that, insufficient teamwork will adversely affect the institutional performance.

Table4. Variables that can be used as incentives for employees

\begin{tabular}{|l|c|c|c|c|c|c|c|}
\hline \multicolumn{1}{|c|}{ Variables } & $\mathbf{1}$ & $\mathbf{2}$ & $\mathbf{3}$ & $\mathbf{4}$ & $\mathbf{5}$ & $\begin{array}{c}\text { Mean } \\
(\underline{\boldsymbol{x}})\end{array}$ & SD \\
\cline { 2 - 7 } & $\mathbf{\%}$ & $\mathbf{\%}$ & $\mathbf{\%}$ & $\mathbf{\%}$ & $\mathbf{\%}$ & 2.70 & 1.103 \\
\hline Annual bonus on financial targets & $20 \%$ & $20 \%$ & $30 \%$ & $30 \%$ & - & 2.50 & 1.208 \\
\hline Extra day off & $30 \%$ & $20 \%$ & $20 \%$ & $30 \%$ & - & 2.40 & 1.433 \\
\hline Employee of the month & $40 \%$ & $20 \%$ & $10 \%$ & $20 \%$ & $10 \%$ & 2.40 \\
\hline Award ceremonies & $10 \%$ & $50 \%$ & $10 \%$ & $20 \%$ & $10 \%$ & 2.70 & 1.191 \\
\hline Publication in university's magazine & $20 \%$ & $30 \%$ & $30 \%$ & $20 \%$ & - & 2.50 & 1.028 \\
\hline Verbal praise & $20 \%$ & $60 \%$ & $10 \%$ & $30 \%$ & - & 2.50 & 1.121 \\
\hline Opportunities for promotion & $10 \%$ & $50 \%$ & $10 \%$ & $20 \%$ & $10 \%$ & 2.70 & 1.191 \\
\hline $\begin{array}{l}\text { Sponsorship for training, seminar and } \\
\text { further studies }\end{array}$ & $20 \%$ & $60 \%$ & - & $20 \%$ & $20 \%$ & 2.80 & 1.474 \\
\hline Free tickets to theatres or cultural events & $50 \%$ & $40 \%$ & $10 \%$ & - & - & 1.60 & 0.665 \\
\hline
\end{tabular}

Key: 1 = No motivational effect, 2 = low motivational effect, 3 = Average motivational effect, $4=$ Good motivational effect, $5=$ High motivational effect.

The data from Table 4 indicates that respondents are of the view that sponsoring employees for training, seminars and further studies can be a useful incentive approach which will improve employees' motivation. This received a mean score of 2.80 , the highest mean score among the other approaches presented as variables. This result is not unexpected since the institution under study is an educational institution which places much emphasis on academic knowledge.

Also, three other incentive approaches received an equal mean value of 2.70. These approaches are 'annual bonuses on financial targets', 'award ceremonies', and opportunities for promotion. Once again, as has already been pointed out earlier, financial bonuses come to the scene together with award ceremonies and promotions. Human resource experts have argued that the single most important incentive or motivational approach for employees is financial rewards ${ }^{\text {[43] [39] [44] }}{ }^{\text {. And this is }}$ evidently seen in the results given here.

Further, three incentive items again scored same mean values of 2.50. This means that respondents rated them to be of equal importance in improving employees' motivation. These items are giving 
'extra day-offs', 'publication in university magazines', and 'verbal praise'. Among these three approaches, verbal praise is of particular interest in the sense that it is a valuable tool yet simple and inexpensive. Researchers assert that when used appropriate at the right time and place, verbal praise can increase employees' motivation significantly. It can thus rival other high-ranking motivation tools like financial rewards and bonuses. ${ }^{[45]}$

'Employee of the month' and 'Free tickets' to theatres or cultural events were rated as the two lowest incentive approaches with mean values of 2.40 and 1.60 respectively.

\section{CONCLUSION}

From the above discussion, it is evident that private tertiary institutions in the country have various incentive mechanisms. As part of the problems facing these private institutions, some components of these incentive packages are not implemented though they exist in the policy document due to inadequate funds. Some of the employees seem not to have enough knowledge of some of these incentives whilst other employees are more concerned with the packages that have direct or instant monetary gains than the non-monetary gains some of which seem to even be of greater value such as the health and safety. Also, the priority needs for most employees do not match with the general priority incentive packages from their institutions. Again, inadequate funds, ineffective communication on the availability of incentives packages as well as inadequate support of the senior members were found to be some challenges facing the smooth running of the incentive management system in the private tertiary education institutions in Ghana. By way of recommendation, the following steps are suggested:

- A restructured incentive of human resource management system is necessary to have the priority needs of the employees taken into consideration.

- There is the need to have a comprehensive mode of communication on the incentive packages for the employees to know, understand, share their concerns and appreciate the system.

- Adequate funds should be set or allocated for the execution of incentives packages for the employees.

- The human resource management incentive policy should include and intensify penalties to employees who negatively do things to affect the institution in ways so as to deter others from repeating similar actions.

- The HRM team should develop effective human resource techniques centered appropriate performance appraisal, monitoring and supervision and prescribe commensurate rewarding systems.

\section{REFERENCES}

[1] Chemekov, A., Practical importance of motivation on employees' performance., Moscow: Routledge Press, 2002.

[2] Badu-Smith, J., "The need for Polytechnics to assert and create a niche for themselves among Tertiary Institutions in Human Resource Development.," Journal of Polytechnics in Ghana., vol. 1, no. 1, pp. 72 83, 2005.

[3] Armstrong, M., and Armstrong, K. , Armstrongs' Handbook of Human Resource Management Practice, Beulah: Kogan Page Limited, 2009.

[4] Baron, D. P., "Incentive Contracts and Competitive Bidding.," American Economic Review, vol. 62, no. 3, pp. 384 - 394, 1972.

[5] Laffont, J. J. and Martimort, D., The Theory of Incentives: The principal-agent model., Woodstock: Princeton University Press, 2002.

[6] Bower, D., Ashby, G., Gerald, K. and Smyk, W. , "Incentive Mechanisms for Project Success.," Journal of Management in Engineering., vol. 18, no. 2, pp. 34 - 43, 2002.

[7] Organisation, International Labour, "Employment and Conditions of Work in Health and Medical Services," in ILO Conference, Geneva, 1985.

[8] Spence, J. R. \& Keeping, L., "Conscious rating distortion in performance appraisal: A review, commentary and prposed framework for research.," Human Resource Management Review, vol. 21, no. 2, pp. 85-95, 2017. 
[9] Handy, C., Understanding Organizations., London: Penguin, 1993.

[10] Jenkins, J. R. G., Mitra, A., Gupta, N., and Shaw, J. D., "Are Financial Incentives Related to Performance? A Meta Review of Empirical Research.," Journal of Applied Psychology, vol. 83, no. 2, pp. 777 - 787, 1998.

[11] Cohen, L., Manion, L., and Morrison, K. , Research Methods in Education, New York.: Routledge, 2007.

[12] Stavrou, E. T., "Flexible work bundles and organizational competitiveness: A cross-national study of the European work context.," Journal of Organizational Behaviour., vol. 26, no. 8, pp. 923-947, 2015.

[13] Cadsby, C. B., Song, F., and Tapon, F., "Sorting and incentive Effects of Pay-For-Performance: Summary of an experimental study.," Academy of Management Journal, vol. 50, no. 6, pp. 384 - 405, 2007.

[14] Adams, O., and Hicks, V. , "The effects of economic and policy initiatives on provider practice: Summary of country case studies using WHO framework.," in World Health Organisation, Geneva, 2000.

[15] Imhorf, I. and Mathauer, I., "Health worker motivation in Africa: The role of Non-financial incentives and Human Resource Management Tools.," Human Resoruce for Health, vol. 4, no. 24, pp. 88-97, 2006.

[16] UNDP, "Incentive systems: Incentive, motivation and development performance.," in UNDP Capacity Development Resource, Prague, 2006.

[17] Burkhauser, M., Collins, A., and Tinkew, J. B., "Using incentive to increase participation in out-of school time program.," Practitioner Insights, vol. 25, no. 2, pp. 25 - 35, 2008.

[18] Moser, E. K., Hartman, R. J., and Kurtz, E. M., Incentive program to improve transit employee performance., vol. 8, Washington DC: National Academic Press, 1994, pp. 14 - 22.

[19] Stilwell, B., Zurn, P. and Dolea, L., "Nurse retention and recruitment: Developing a motivated workforce.," Issue4retention.pdf, www.icn.ch/Global, 2005.

[20] Murlis, H., and Armstrong, M. , Reward managemenet: A handbook of remuneration strategy and practice., London: Kogan Page, 2004.

[21] Griffin, D. E., "Human resource management and performance: A review and research agenda.," International Journal of Human Resource Management, vol. 8, no. 3, pp. 263 - 276, 2008.

[22] Reiche, S., "The effect of international staffing practices on subsidiary staff retention in multinational corporations.," The International Journal of Human Resource Management., vol. 21, no. 3, pp. 32-37, 2007.

[23] Paauwe, J. \& Boselie, P. , "Challenging Strategic HRM and the Relevance of the Institutional Setting.," Human Resource Management Journal., vol. 13, no. 3, pp. 56 - 70, 2016.

[24] McShane, A., and Rydval, O., "How financial incentive and cognitive abilities affect task performance in laboratory setting: An illustration.," Economic Letters, vol. 8, no. 5, pp. 315 - 320, 2000.

[25] Herzberg, F. W., Mauser, W., and Syndermann, B., The motivation to work., New York: Wiley, 1959.

[26] Harvey, S. J., "Why did you do that? An economic examination of the effect of extrinsic compensation on intrinsic motivation and performance.," Journal of Economic Psychology, vol. 26, no. 1, pp. 549 - 566, 2005.

[27] Obiekwe, N. , "Employee motivation and performance," Centria University of Applied Sciences. Unpublished Masters' Thesis, 2016.

[28] Martin, T. N., "Job performance and turnover.," Journal of Applied Psychology, vol. 66, no. 1, pp. 116 119, 1988.

[29] Dessler, C., Essentials of Behaviour, New Haven City: Yale University Press, 2008.

[30] Purcell, J., Kimmie, K., Hutchinson, R. B., and Swart, J., People and performance: How people management impacts on organisational performance., London: CIPD, 2003.

[31] Wilson, Thomas B., Innovative reward systems for the changing workplace., New York: McGraw Hill, Inc., 2017.

[32] Sujatha, I., Korey, K. R., Anmya, B., "Flexible work bundles and organizational competitiveness: a crosssectional study of the European work context.," Journal of organisational behaviour., vol. 26, no. 8, pp. 923-947, 2005.

[33] Allison, A. and Kawin, I. , "The role of financial and moral incentives on rasising performance level of employee from the viewpoing of the security officer involved in the pilgrimage season.," Master Thesis, vol. 2, no. 5, pp. 200-205, 2005.

[34] Holtman, J. M., and Grammling, L., "Contrast effects in performance evaluation and rewards practices.," The academy of management journal., vol. 26, no. 3, pp. 465 - 476, 2005.

[35] Arthur, J. B., "Effects of human resource systems on manufacturing performance and turnover.," Academy of management journal, vol. 37, no. 1, pp. 670 - 687, 1994. 
[36] Heany, M., Amabile, T. M., Conti, R., Coon, H., and Lazenby, J. , "Assessing the work environment for creativity.," Academy of management journal., vol. 39, no. 5, pp. 1154 - 1184, 1994.

[37] Ahmed, A. S., Zhou, J., and Lobo, G. J. , "Job security and income smoothing: An empirical test of the Fudenberg and Tirole (1995) model.," Available at SSRN, vol. 8, no. 8, pp. 24 - 82, 2002.

[38] Silla, E. A., Decenzo, D. D. and Robbins, S. P., Personnel and Human Resource Management., New Delhi: Prentice Hall of India, 2009.

[39] Nsiah-Gyabaah, K., "Implications for capacity building and institutional strenghtening in the Polytechnics in Ghana.," Journal of polytechnics in Ghana., vol. 1, no. 1, pp. 49 - 59, 2005.

[40] Oliver, B. K., Intrinsic and extrinsic motivation: The search for optimal motivation and performance., San Diego: Academic press., 1997.

[41] Cohen, H. and Bailey, P, "Building the capacity for managing public service reform: The Tanzania Experience.," European center for development policy management , vol. 57, no. 1, pp. 1 - 27, 1999.

[42] Crosby, A., Managerial behaviour in contemporary organisations., Amman: Dar Zahran, 1999.

[43] Hussein, U., "Assessment of human resource management practices in the three polytechnics in Northern Ghana.," Unpublished Masters Thesis, 2016.

[44] Gruman, J. A., and Saks, A. M., "Performance management and employee engagement.," Human resource management review, vol. 21, no. 2, pp. 123 - 136, 2011.

[45] Hammuda, I. and Dulaimi, M. F., "The theory and application of empowerment in construction: a comparative study of the different approaches to empowerment in construction, service and manufacturing industries.," International Journal of Project Management., vol. 15, no. 5, pp. 289 - 296, 1997.

[46] Becker, B. E., Huselid, M. A. and Ulrich, D., "The HR Scorecard: Linking people, strategy and performance.," Harvard Business press., vol. 12, no. 3, pp. 199 - 207, 2001.

\section{AUTHORS' BIOGRAPHY}

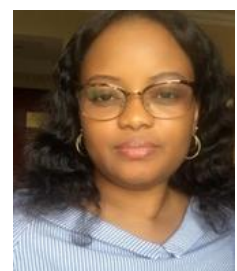

Irene Samari is a graduate of Master of Business Administration from Nanjing University of Posts and Telecommunications. She received her MBA degree in April 2018.Her research interest is mainly focused on human resource management.

Citation: Irene Samari. “ Incentive Mechanisms of Human Resource Management (HRM) in Private Academic Institutions in Ghana " International Journal of Managerial Studies and Research (IJMSR), vol 7, no. 2, 2019, pp. 28-38. doi: http://dx.doi.org/10.20431/2349-0349.0702005.

Copyright: (c) 2019 Authors. This is an open-access article distributed under the terms of the Creative Commons Attribution License, which permits unrestricted use, distribution, and reproduction in any medium, provided the original author and source are credited. 